\title{
Safe water? Depends on where you live!
}

$\mathrm{T}$ he contaminated water tragedy in Walkerton, Ontario, in 2000, which caused the deaths of 7 people and illness in at least 2300 others, rocked Canadians' belief that our public water supply was safe. Nevertheless, after 8 years and millions of dollars spent on regulation, systemic problems persist. Although Ontario has made several important improvements, and most provinces have tightened their oversight somewhat, an inherent structural flaw remains. Providing consistently safe drinking water requires well-resourced treatment systems and highly trained personnel, yet we download this responsibility to local governments. Larger municipalities generally do well, but many smaller and more remote communities simply cannot cope with all the technical and managerial challenges. For example, boil-water advisories - a measure of last resort - are all too common. We are allowing a two-tier system of water supply, roughly split along the urban-rural divide. (See related news article, page 985.)

Paradoxically, although necessary improvements are often opposed as being too costly, Canadians consume more water domestically per capita than anyone in the world and our cost is among the world's lowest. Our indifference feeds the lack of political will to face the challenge. For example, Ontario shelved a 2005 expert panel report that recommended consolidating water systems to achieve economies of scale combined with full cost accounting and pricing of water to assure sustainability and safety. ${ }^{1}$ Alberta has achieved some success by pursuing regionalization with treated water pipelines, improving water safety in smaller communities. This approach still faces technical difficulties (e.g., many remote small systems are difficult to reach) and political opposition (e.g., some communities do not want to relinquish control of their water utility).

Australia has faced, and overcome, similar difficulties. In Western Australia and South Australia publicly owned statewide corporations are responsible for drinking water in virtually every community. In 1993, the state of Victoria collapsed about I20 small organizations into I5 viable water companies. Today the Australian water industry has achieved a level of coherence and maturity that has allowed it to influence public policy and establish its own research agenda.

Canada could do likewise. With enlightened leadership and appropriate incentives, larger regional drinking water authorities could achieve economies of scale and deliver the technical and managerial expertise required to ensure safe water for all Canadians. For remote, smaller communities, including many First Nations reserves, we need to pursue the regional pooling of operational and managerial expertise, combined with modern remote monitoring technology. Regardless of location, it is essential that all delivered water be metered and that billing reflects the actual cost of assuring safe water. In addition, water providers must invest in paying, training and recognizing staff as essential public health professionals.
By ignoring the systemic flaws and avoiding the logical steps needed to improve municipal water systems, we promote a divide between those who rely on municipal supplies and those with the resources to buy home water-treatment equipment or bottled water, which costs Iooo times what we typically pay for good tap water. In Canada, per capita bottled water consumption grew 40\% from 1999 to $2004 .{ }^{2}$ Remarkably, the increasing popularity of these products comes at a time when Canadians appear largely indifferent to investing in high-quality community water supplies. If we continue the trend, Canada could find itself emulating the poorer regions of the world where high-quality, safe drinking water is only accessible to the rich.

Health professionals, more than most citizens, know that the provision of safe water, immunization and the development of antibiotics have been the main interventions for improving population health status over the past century. You, our readers, are uniquely placed to be influential in developing Canada's community drinking-water systems.

You can begin by determining the competency of your local drinking-water utility. Ask about the qualifications of its staff and the measures taken to assure that the water is safe. Does it meter the water delivered and invest all of its revenue in improving its service? Challenge those local politicians who treat your water utility as a cash cow to fund unrelated projects, who oppose sensible investments in drinking-water systems as being too costly, or who oppose sensible regionalization options. Safe community drinking water is one of our best public health investments. Surely we do not need another Walkerton disaster to help us appreciate the true value of our community water supply.

\section{Steve E. Hrudey DSc(Eng) PhD}

Professor Emeritus, School of Public Health

University of Alberta

Edmonton, Alta.

With the Editorial-Writing Team (Paul C. Hébert MD MHSc, Matthew B. Stanbrook MD PhD, Barbara Sibbald BJ, Ken Flegel MDCM MSc, Noni MacDonald MD MSc and Amir Attaran LLB DPhil)

Competing interests: None declared.

\section{REFERENCES}

I. Watertight: the case for change in Ontario's water and wastewater sector. Report of the Water Strategy Expert Panel; Swain H, Lazar F, Pine J. Toronto: Queen's Printer for Ontario; 2005. Available: www.pir.gov.on.ca/english/aboutpir/publications /Watertight-panel_report_EN.pdf (accessed 2008 Mar 4).

2. Gleick PH, Wolff GH, Cooley H. Table I3: Per Capita Bottled Water Consumption, by Country, 1999 to 2004 . In: The world's water, the biennial report on freshwater resources: 2006-2007. Washington: Island Press; 2006. p. 284-286. Available: www.worldwater.org/data20062007/Tableı3.pdf (accessed 2008 Mar 5). 